\title{
Photoinduction of UV-absorbing compounds in six species of marine phytoplankton
}

\author{
Gabriela Hannach*, Anne C. Sigleo** \\ U.S. Environmental Protection Agency, Western Ecology Division, 2111 SE Marine Science Drive, Newport, Oregon 97365, USA
}

\begin{abstract}
High fluence PAR (photosynthetically active radiation, $400-700 \mathrm{~nm}), \mathrm{UV}-\mathrm{A}(320-400 \mathrm{~nm})$, and UV-B $(280-320 \mathrm{~nm})$ radiation were tested for their ability to stimulate the production of UV-absorbing mycosporine-like amino acids (MAAs) in 6 diverse species of marine phytoplankton. Dunaliella tertiolecta, Thalassiosira weissflogii, Pyramimonas parkeae, Pavlova gyrans and Isochrysis sp. were grown under (1) low fluence PAR (LL, 25 to $75 \mu \mathrm{mol}$ photons $\mathrm{m}^{-2} \mathrm{~s}^{-1}$ ), (2) high fluence PAR (HL, 255 to $290 \mu$ mol photons $\mathrm{m}^{-2} \mathrm{~s}^{-1}$ ), (3) PAR+UV-A (240 to $268 \mu \mathrm{mol}$ photons $\mathrm{m}^{-2} \mathrm{~s}^{-1}$ and $4910 \mathrm{~mW} \mathrm{~m}^{-2}$, respectively) and (4) PAR+UV-A+UV-B (103, 216, or $304 \mathrm{~mW} \mathrm{~m}^{-2}$ weighted UV-B). Amphidinium carterae was grown under similar conditions in LL but reduced levels of PAR and UV radiation were used in the other treatments. UV-B supplementation caused a significant depression (23-57\%) in the chl a-specific growth rate of all species except $P$. gyrans, which received the second lowest UV-B dose. The quantum yield of fluorescence for photosystem II declined by $4-17 \%$ with exposure to UV-A and/or UV-A+UVB. The 2 prymnesiophytes exhibited the highest and the dinoflagellate the lowest resistance to UV-B radiation. In vivo absorption spectra indicated that only $P$. gyrans has a pronounced UV maximum. Of the 3 MAA compounds detected in $P$. gyrans, only 1 with peak absorption in the UV-A range was photoinducible. The other species examined exhibited relatively small in vivo UV absorption peaks. In these species, only 1 MAA was detected, a compound with peak absorption in the UV-B range and limited inducibility. UV-B radiation more effectively induced MAAs than UV-A or HL in 4 of the 6 species. In P. gyrans large increases in the concentration of the inducible MAA were obtained with HL and with UV-A+UV-B radiation. Relative to LL cells, UV-B-exposed $P$. gyrans exhibited a 145 -fold MAA increase accompanied by an 11 -fold increase in the in vivo UV absorption. In all other species HL had minimal or no effect on MAA production. UV-A radiation effectively increased the chl a-specific MAA content in Isochrysis sp. $(77 \%), T$ weissflogii $(73 \%)$, and $P$. parkeae $(43 \%)$, and UV-B supplementation increased it by a further $141 \%$ in Isochrysis sp. and $95 \%$ in P. parkeae. On a cell volume basis, UV-B also approximately doubled the MAA concentration in the latter 2 species. We conclude that, although MA.As may be commonly present in phytoplankton cells, an ability to produce significant amounts of these compounds through photoinduction is limited to certain species or taxa, particularly some prymnesiophytes and dinoflagellates.
\end{abstract}

KEY WORDS: UV · UV-B radiation - Phytoplankton · Mycosporine-like amino acids · Photoprotection

\section{INTRODUCTION}

Compounds that selectively absorb ultraviolet (UV) radiation are found in a wide variety of terrestrial (Caldwell et al. 1983), freshwater (Garcia-Pichel \& Castenholz 1993) and marine (Karentz et al. 1991b)

\footnotetext{
- Present address: School of Fisheries, Box 355100 , University of Washington, Seattle, Washington 98195, USA

- Addressee for correspondence.

E-mail: sigleo.anne@epamail.epa.gov
}

photoautotrophs, and may play an important role in providing protection from deleterious UV wavelengths (Garcia-Pichel et al. 1993, Landry et al. 1995). Mycosporine-like amino acids (MAAs) form the most common class of UV-absorbing compounds in marine organisms (Karentz et al. 1991b). These compounds presumably are synthesized by marine algae (Karentz 1994) and have absorption maxima ranging from 310 to $360 \mathrm{~nm}$ (Nakamura et al. 1982). Because they occur in compound mixtures they exhibit a broad in vivo absorption peak, most often in the UV-A (320-400 nm) 
region of the spectrum (Garcia-Pichel \& Castenholz 1993, Davidson \& Marchant 1994).

MAAs have been isolated and identified from a number of free-living marine phytoplankton species (Carreto et al. 1990a, b, Ferreyra et al. 1994, Lesser 1996, Vernet \& Whitehead 1996), and a UV-absorbance peak suggesting the presence of MAAs has been recorded from unialgal cultures (Yentsch \& Yentsch 1982, Marchant et al. 1991, Davidson et al. 1994) and from natural phytoplankton assemblages (Ferreyra et al. 1994, Vernet et al. 1994, Montecino \& Pizarro 1995). A few species, e.g. the dinoflagellate Alexandrium excavatum (Carreto et al. 1990a, b) and the prymnesiophyte Phaeocystis pouchetii (Marchant et al. 1991, Davidson \& Marchant 1994), are known to produce MAAs in high concentrations. In Antarctica, high in vivo absorption at wavelengths indicative of MAAs was characteristic of assemblages dominated by prymnesiophytes (Vernet et al. 1994) and by the chain-forming diatom Thalassiosira gravida (Ferreyra et al. 1994). The presence of UV-absorbance peaks, however, is not ubiquitous among marine phytoplankton. For example, some antarctic diatom populations may contain substantial amounts of UV-absorbing compounds (Ferreyra et al. 1994), whereas others have low concentrations of UV-absorbing compounds (Karentz et al. 1991a, Davidson \& Marchant 1994, Davidson et al. 1994). Studies in the Southeastern Pacific (Montecino \& Pizarro 1995) and in Antarctica (Vernet et al. 1994) also have shown that some assemblages exhibit a pronounced absorption in the UV, whereas others do not.

The role of MAAs as internal UV filters has not been clearly established for marine phytoplankton. Since absorption by MAAs does not interfere with light harvesting for photosynthesis, these compounds could play a significant role in the photoprotection of algae. Some evidence exists for the inducibility and photoprotective function of MAAs in corals (Dunlap et al. 1986, Banaszak \& Trench 1995). MAAs also were shown to reduce UV-induced damage in sea urchin eggs not previously exposed to UV radiation (Adams \& Shick 1996). Assessing the functional value of MAAs is complicated by the occurrence of a suite of cellular functions involved in the UV acclimation response (Karentz 1994, Lesser 1996). Conclusions regarding the photoprotective function of MAAs in algae previously were based on indirect evidence, i.e. correlations between MAA content and UV resistance following UV exposure (Vernet et al. 1994, Villafañe et al. 1994).

The few studies that directly addressed the effects of MAA content on wavelength-dependent inhibition of photosynthesis suggest important species-specific differences in MAA photoprotective value. Photoinhibition at wavelengths absorbed by MAAs was less severe in MAA-rich than in MAA-poor cultures of the dinoflagellate Gymnodinium sanguineum (Neale et al. 1996). Lesser (1996) concluded that UV-absorbing compounds in the dinoflagellate Prorocentrum micans provided incomplete protection from UV damage. In this species, MAA concentrations doubled under supplemental UV radiation, yet the ensuing decrease in photoinhibition at wavelengths absorbed by MAAs was not sufficient to prevent oxidative stress and a reduction in growth. Species-specific differences in the functional value of MAAs can partially be explained by differences in the optical pathlengths among cells of various sizes (Garcia-Pichel 1994), since shorter pathlengths will limit the protection of intracellular targets.

Photoinducible production of UV-absorbing compounds may improve the ability of a population to acclimate to changes in the UV environment. With the decrease in stratospheric ozone from anthropogenic inputs of chlorinated fluorocarbons there has been a gradual increase in the amount of harmful UV radiation reaching the ocean surface (Kerr \& McElroy 1993). Since only wavelengths shorter than about $320 \mathrm{~nm}$ are significantly enhanced due to ozone depletion (Crutzen 1992) the effectiveness of UV-B $(280-320 \mathrm{~nm})$ wavelengths for MAA induction deserves special attention.

There is limited evidence as to the inducibility of MAAs in phytoplankton. MAA accumulation may occur as a result of UV-induced alterations in the synthesis of amino acids (Goes et al. 1995). High fluence PAR (photosynthetically active radiation, $400-700 \mathrm{~nm}$; Carreto et al. 1990a), blue light (400-500 nm; Carreto et al. 1990b), UV-A (Carreto et al. 1990b, Ferreyra et al. 1994) and UV-B wavelengths (Davidson \& Marchant 1994, Lesser 1996) have been implicated in the induction response. On the other hand, MAA production proved insensitive to UV-B radiation in 5 common antarctic diatoms (Davidson et al. 1994).

The present study examines the inducibility of UVabsorbing compounds in 6 diverse species of marine phytoplankton. High fluence PAR, UV-A, and UV-B radiation are tested for their ability to stimulate MAA production, as a step towards understanding the universality and photoinducibility of this group of UVabsorbing compounds in microalgal assemblages.

\section{MATERIALS AND METHODS}

Cultures and experimental conditions. Unialgal batch cultures of Dunaliella tertiolecta Butcher (Chlorophyceae), and Thalassiosira weissflogij (Grunow) Fryxell et Hasle (Bacillariophyceae) in Expt $A_{\text {, }}$ Pavlova gyrans Butcher (UW349, CCMP607, Prymnesiophyceae) in Expt B, and Pyramimonas parkeae Norris et Pearson (UW442, CCMP724, Prasinophyceae). Isochrysis sp. (UW635, Prymnesiophyceae), and Am- 
phidinium carterae Hulburt (Dinophyceae) in Expt C were grown in an environmental growth chamber under 2 irradiance regimes. In the first regime, (1) low and (2) high fluence PAR without supplementary UV radiation (PAR-only treatments) were used. The second regime consisted of (1) PAR supplemented with UV-A radiation (PAR+UV-A treatment), and (2) PAR supplemented with UV-A and UV-B radiation (PAR+ UV $-A+U V-B$ treatment). D. tertiolecta was originally isolated from Puget Sound, Washington (USA), $T$. weissflogii from Long Island, New York (USA), and A. carterae from Brixham Harbor, England. Cultures of these species were obtained from the collection at the School of Oceanography, University of Washington. $P$. gyrans, P. parkeae and Isochrysis sp. were obtained from the culture collection at the Department of Botany, University of Washington. With the exception of $P$. gyrans, cells were grown in $\mathrm{f} / 2$ medium (Guillard \& Ryther 1962) prepared with natural seawater from Yaquina Bay, Oregon (USA). For P. gyrans, the same enrichment was added to artificial seawater (Spotte et al. 1984). Cultures were gently inverted once a day.
Sterile techniques were used for all culture work to minimize bacterial growth. PAR-only cultures were grown for 4 to $9 \mathrm{~d}$, depending on growth rate, and harvested during exponential growth. UV-exposed cultures were grown for an additional 3 to $7 \mathrm{~d}$ prior to final harvest.

The PAR-only cultures were grown under white light alone prior to the setup of the UV-exposure cultures in the same growth chamber to examine the effect of photon fluence density (PFD) on production of UVabsorbing compounds, and to generate a population of high-light-acclimated cells for subsequent UV exposure treatments. Low light (LL) and high light (HL) PAR-only cultures were inoculated to an initial concentration of $10 \mu \mathrm{g} \mathrm{chl} \mathrm{a} \mathrm{l}^{-1}$ from stock cultures that had been maintained at $16^{\circ} \mathrm{C}$ and $45 \mu \mathrm{mol}$ photons $\mathrm{m}^{-2} \mathrm{~s}^{-1}$ for $5 \mathrm{~d}$ prior to the inoculation to achieve log growth. After inoculation, the PAR-only cultures (400 ml) were grown at $18^{\circ} \mathrm{C}$ in $0.5 \mathrm{l}$ pyrex Erlenmeyer flasks without replication on a $16 \mathrm{~h}$ light: $8 \mathrm{~h}$ dark photoperiod, delivered as a stepwise function to simulate daily changes in solar radiation (Behrenfeld et al. 1994). Maximum

Table 1. Irradiances for PAR-only (LL: low light, HL: high light) and UV-exposed (PAR+UV-A, PAR+UV-A+UV-B) cultures. PAR values shown correspond to peak photon fluence densities (PFDs) provided for $8 \mathrm{~h}$ of the $16 \mathrm{~h}$ light period. UV-A and UV-B radiation were supplemented for 8 and $5 \mathrm{~h} \mathrm{~d}^{-1}$, respectively. PAR-only cultures were grown in pyrex flasks without replication. UV-

exposed cultures were grown in teflon bottles covered by appropriate UV-blocking filters, with 3 replicates per treatment

\begin{tabular}{|c|c|c|c|c|c|}
\hline \multirow[t]{2}{*}{ Species } & \multirow[t]{2}{*}{ Treatment } & \multirow{2}{*}{ 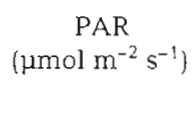 } & \multicolumn{3}{|c|}{ UV irradiance $\left(\mathrm{mW} \mathrm{m}^{-2}\right)$} \\
\hline & & & $\begin{array}{c}\text { UV-A } \\
(320-400 \mathrm{~nm})\end{array}$ & $\begin{array}{l}\text { Unweighted UV-B } \\
\quad(286-320 \mathrm{~nm})\end{array}$ & $\begin{array}{l}\text { Weighted UV-B } \\
(286-320 \mathrm{~nm})\end{array}$ \\
\hline \multirow[t]{4}{*}{ Dunaliella tertiolecta } & LL & 75 & & & \\
\hline & HL & 290 & & & \\
\hline & $\mathrm{PAR}+\mathrm{UV}-\mathrm{A}$ & 263 & 4910 & 30.7 & 4.0 \\
\hline & $P A R+U V-A+U V-B$ & 268 & 5730 & 732.0 & 304.2 \\
\hline \multirow[t]{4}{*}{ Thalassiosira weissflogii } & LL & 75 & & & \\
\hline & $\mathrm{HL}$ & 290 & & & \\
\hline & $P A R+U V-A$ & 263 & 4910 & 30.7 & 4.0 \\
\hline & $P A R+U V-A+U V-B$ & 268 & 5730 & 732.0 & 304.2 \\
\hline \multirow[t]{4}{*}{ Isochrysis $\mathrm{sp}$. } & LL & 29 & & & \\
\hline & $\mathrm{HL}$ & 270 & & & \\
\hline & $\mathrm{PAR}+\mathrm{UV}-\mathrm{A}$ & 263 & 4910 & 30.7 & 4.0 \\
\hline & $P A R+U V-A+U V-B$ & 268 & 5730 & 732.0 & 304.2 \\
\hline \multirow[t]{4}{*}{ Pyramimonas parkeae } & $L L$ & 25 & & & \\
\hline & $\mathrm{HL}$ & 255 & & & \\
\hline & PAR+UV-A & 263 & 4910 & 30.7 & 4.0 \\
\hline & $\mathrm{PAR}+\mathrm{UV}-\mathrm{A}+\mathrm{UV}-\mathrm{B}$ & 259 & 5250 & 591.0 & 216.4 \\
\hline \multirow[t]{4}{*}{ Pavlova gyrans } & LL & 33 & & & \\
\hline & $\mathrm{HL}$ & 280 & & & \\
\hline & $\mathrm{PAR}+\mathrm{UV}-\mathrm{A}$ & 263 & 4910 & 30.7 & 4.0 \\
\hline & $P A R+U V-A+U V-B$ & 240 & 4380 & 320.1 & 102.7 \\
\hline \multirow[t]{4}{*}{ Amphidinium carterae } & LL & 27 & & & \\
\hline & $\mathrm{HL}$ & 120 & & & \\
\hline & $\mathrm{PAR}+\mathrm{UV}-\mathrm{A}$ & 73 & 1290 & 7.5 & 1.4 \\
\hline & $P A R+U V-A+U V-B$ & 76 & 1580 & 171.1 & 72.3 \\
\hline
\end{tabular}


PFDs, supplied for $8 \mathrm{~h}$ in the center of the light period, are listed in Table 1. Illumination was provided by a ceiling mounted combination of high output daylight fluorescent lamps (Philips F72T12/D/VHO) and $60 \mathrm{~W}$ incandescent bulbs (see Fig. 1 in Behrenfeld et al. 1994 for emission spectrum). Light was attenuated by covering LL culture vessels with neutral density screening. No UV-blocking filters were used for PAR-only cultures.

Exponentially growing HL cultures (LL culture in the case of Amphidinium carterae) provided the inocula for the UV exposure treatments. Three replicates per UV treatment were inoculated to an initial concentra-

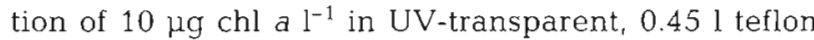
bottles wrapped with mylar (315 nm cutoff) for the PAR+UV-A treatment or with cellulose acetate $(290 \mathrm{~nm}$ cutoff) for the PAR+UV-A+UV-B treatment. The mylar film was replaced daily, the cellulose acetate film every $3 \mathrm{~d}$. Temperature and PAR conditions were similar to those described above for PAR-only cultures. UV-A and UV-B radiation were provided for 8 and $5 \mathrm{~h}$ $\mathrm{d}^{-1}$, respectively, in the center of the $16 \mathrm{~h}$ light period by a bank of alternating UV-A340 and UV-B313 fluorescent lamps (National Biological Corporation) positioned vertically between each of the culture vessels. UV-B exposures were adjusted according to the sensitivity of each species by varying the number of layers of cellulose acetate film: 1 layer for Dunaliella tertiolecta, Thalassiosira weissflogii, Isochrysis sp., and $A$. carterae, 2 layers for Pyramimonas parkeae, and 4 layers for Pavlova gyrans. Varying filter thickness causes spectral shifts that are comparable to those caused by variations in the thickness of the stratospheric ozone layer (Rundel 1983). Cultures of $A$. carterae additionally were covered by neutral density screens attenuating 72 to $77 \%$ of all visible and UV radiation. PAR and UV dose rates in our experimental cultures are listed in Table 1 . We have compared these dose rates with values from solar scans performed with the same instrument at the Hatfield Marine Science Center $\left(45^{\circ} \mathrm{N}\right)$ in 1991. Based on the same biological weighting function (Cullen et al, 1992), UV-B dose rates in our cultures ranged from 9 to $36 \%$ of summer, and from 31 to $132 \%$ of winter near-noon UV-B radiation values. UV-A/UV$B$ ratios (based on unweighted dose rates) in our cultures ranged from 8 to 14 , and were thus somewhat lower than the ratio of 18 determined from the solar scans.

PFDs in PAR-only cultures were measured using a Licor quantum meter with a $2 \pi$ cosine collector. PAR and UV radiation in the UV-exposed cultures were measured at $1 \mathrm{~nm}$ increments using an Optronic 752 spectroradiometer with a $2 \pi$ cosine collector. To estimate the total irradiance received by the cultures (i.e. the irradiance coming from all directions) separate spectral scans were made with the collector pointing upwards and downwards. The wavelength-specific contribution of the latter to the total irradiance (upwards + downwards) was thus estimated and subsequently used as a correction for scans performed only in the upwards position. A teflon bottle cut in half and covered by the appropriate optical filters and/or screens was positioned over the light collector for measurements of spectral irradiance in UV-exposed cultures. Reported PAR and UV dose rates for UV. exposed cultures (Table 1) are based on spectral scans made at a single near-center position in the chamber. Behrenfeld et al. (1994) report a 16\% gradient in PAR within the same chamber, but uniform UV-A and UV-B conditions throughout due to separate lamps for each vessel location. All radiation measurements were done in air and no corrections for light extinction in the cultures were made.

Growth, cell volume and fluorescence. Chlorophyll $a$-specific growth rates were estimated for all species from daily measurements of in vivo, DCMU[3-(3,4-dichlorophenyl)-1,1-dimethylurea] enhanced chl a fluorescence (Vincent 1980). Fluorescence was measured with a Turner Designs 10-005R fluorometer at the beginning of the light period, following 30 to 45 min adaptation in the dark $\left(F_{0}\right)$, and then again after addition of $2 \times 10^{-5} \mathrm{M}$ of the electron flow inhibitor DCMU in water $\left(F_{\mathrm{m}}\right), F_{0}$ and $F_{\mathrm{m}}$ were recorded after $60 \mathrm{~s}$ in the fluorometer. Chl $a$-specific growth rates were estimated from linear regressions of $\ln F_{\mathrm{m}}$ versus time during the exponential phase of growth, assuming no significant changes in the $F_{\mathrm{m}}$ :chl $a$ ratio during the growth period. The relationship between $F_{\mathrm{m}}$ and chl a concentration was determined by linear regression analysis on samples collected at the end of each growth period and extracted in $90 \%$ acetone or $100 \%$ methanol following measurements of in vivo fluorescence. Regressions based on all extracted samples yielded the following $\mathrm{R}^{2}$ values: Dunaliella tertiolecta, $0.980(\mathrm{n}=13)$; Thalassiosira weissflogii, $0.925(\mathrm{n}=19)$;

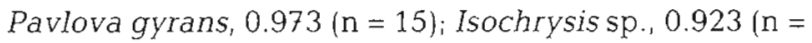
20); Pyramimonas parkeae, $0.980(\mathrm{n}=18)$; Amphidinium carterae, $0.943(\mathrm{n}=15)$. The cellular fluorescence capacity (CFC) index was calculated as $\left(F_{\mathrm{m}}-\right.$ $\left.F_{0}\right) / F_{\mathrm{m}}$ (where $F_{\mathrm{m}}-F_{0}$ is equivalent to variable fluoresence, $\left.F_{\mathrm{v}}\right)$ and used as a measure of photochemical capacity, i.e. the quantum yield of fluorescence for photosystem II (PS II) (Vincent 1980, Falkowski \& Kiefer 1985).

Cell-specific growth rates were estimated for species in Expt $\mathrm{C}$ from daily cell counts, determined within $2 \mathrm{~h}$ of the onset of the light period, using an El-Zone 80XY electronic particle counter. Cell volumes were estimated from mean cell dimensions obtained from the El-Zone, assuming spherical shapes. 
In vivo absorption spectra. At the end of the growth period, cells were collected by gentle filtration (differential pressure < $1 \mathrm{Hg}$ ) onto $25 \mathrm{~mm}$ Whatman $\mathrm{GF} / \mathrm{F}$ glass fiber filters. Spectra (250 to $750 \mathrm{~nm}$ ) were recorded immediately with a Shimadzu UV-2101PC double beam spectrophotometer equipped with an integrating sphere (ISR-260). The sample filter was mounted at one entrance port to the integrating sphere and a clean filter saturated with distilled water was used as the reference at the other port. Blanks were prepared by filtering appropriate volumes of growth medium and their spectra subtracted from sample spectra. Sample filters were carefully extracted in hot methanol and scanned again to determine absorption due to the non-pigmented fraction (Kishino et al. 1985). The digitally stored spectra were corrected for residual scattering by subtracting the optical density at $750 \mathrm{~nm}$ and for pathlength amplification (Mitchell 1990). For PAR-only cultures, 2 duplicate samples per culture were scanned and averaged. For UV-exposed cultures, 1 sample per culture was scanned and the spectra from the 3 replicate cultures were averaged. Pigment-specific spectral absorption coefficients were calculated from these spectra and the concentrations of chl a obtained from pigment extracts.

Pigment extractions. Cells were collected by filtration onto $25 \mathrm{~mm}$ Whatman GF/F glass fiber filters and extracted in $2 \mathrm{ml} 100 \%$ methanol or $90 \%$ acetone for at least $24 \mathrm{~h}$ at $-15^{\circ} \mathrm{C}$ in the dark. Extracts were clarified by filtration $(0.2 \mu \mathrm{m})$. Methanol extracts were scanned $(250-750 \mathrm{~nm})$ with a Shimadzu UV-2101PC double beam spectrophotometer to determine presence of UVabsorbing compounds and stored at $-80^{\circ} \mathrm{C}$ for analysis by high pressure liquid chromatography (HPLC) without further treatment. Chl a concentrations were determined from the methanol extracts using (1) the provisional equation of Humphrey \& Jeffrey presented in Jeffrey \& Haxo (1968) for species containing chls $a$ and C (Thalassiosira weissflogij, Isochrysis sp., Pavlova gyrans, Amphidinium carterae) or (2) the equation of Porra et al. (1989) for species containing chls $a$ and $b$ (Dunaliella tertiolecta, Pyramimonas parkeae). For a comparison of methods some chl a concentrations were also determined in $90 \%$ acetone extracts (Jeffrey \& Humphrey 1975) of UV-exposed cultures. In D. tertiolecta, $T$. weissflogii and P. gyrans chl a estimates from methanol extracts were within $7 \%$ of estimates from $90 \%$ acetone extracts. In P. parkeae, Isochrysis sp. and A. carterae, however, methanol extractions underestimated chl a concentrations by 95,48 and $32 \%$, respectively, relative to $90 \%$ acetone, as determined by linear regression analysis $\left(n=6, R^{2}=0.99,0.97\right.$, and 0.99). The basis for this rather large, yet possibly consistent, discrepancy is unknown. For these species, chl a con- centrations were derived from $90 \%$ acetone extracts when available (UV-exposed cultures) or otherwise from methanol extracts corrected for this discrepancy (PAR-only cultures). Values corrected in this manner are thus restricted to the in vivo absorption coefficients and the chl a-specific MAA contents of $P$. parkeae, Isochrysis sp. and A. carterae in LL and HL treatments, and should be considered tentative.

Analysis of mycosporine-like amino acids. MAAs were separated by reverse-phase isocratic HPLC (Hewlett Packard Series 1050) with a Brownlee RP-8 column (Spheri-5, $4.6 \mathrm{~mm} \times 25 \mathrm{~cm}$ ) protected with an RP- 8 guard column, in an aqueous mobile phase containing $0.1 \%$ acetic acid and $15 \%$ (Thalassiosira weissflogii) or $25 \%$ (all other species) methanol (v:v) at a flow rate of $0.6 \mathrm{ml} \mathrm{m^{-1 }}$ (Dunlap \& Chalker 1986). Detection of peaks was by absorbance at 313 and $340 \mathrm{~nm}$. As MAA standards were not available, peaks were tentatively identified by comparison with published retention times, by the ratio of peak areas determined at 313 and $340 \mathrm{~nm}$, and by co-chromatography with extracts of Pavlova gyrans exposed to UV-B and Porphyra sp. collected at South Beach, Oregon. Identities of major peaks in the latter 2 extracts were confirmed by $\mathrm{A}$. Banaszak. Relative chl a-specific (all species) and cell-volume-specific (Expt $C$ only) MAA concentrations were calculated from peak areas normalized to injection volume, and expressed as peak area (relative units) per ng chl $a$ and peak area per $\mu \mathrm{m}^{3}$, respectively. All the samples of a given species were analyzed on the same run to minimize potential biases from variations in column efficiency.

Significance of UV-A versus UV-A+UV-B treatment effects was evaluated by Student's $t$-test or Welch's approximate $t$-test following an $F$-test for variance homogeneity (Sokal \& Rohlf 1981). Because PAR-only data lack true replication, for these treatments only the standard deviation (SD) is given as a measure of within-culture variation and sampling error.

\section{RESULTS}

\section{Growth rate and cell volume}

Fig. 1 shows growth rates estimated from daily chl a in vivo fluorescence for all 6 species, and Table 2 lists cell-specific growth rates for the 3 species whose growth was in addition estimated from daily cell counts. PAR-only growth rates (Fig. 1) suggest light limitation of Isochrysis sp. and Pyramimonas parkeae at $29 \pm 4 \mu \mathrm{mol}$ photons $\mathrm{m}^{-2} \mathrm{~s}^{-1}$ and light inhibition of Amphidinium carterae at $120 \mu \mathrm{mol}$ photons $\mathrm{m}^{-2} \mathrm{~s}^{-1}$. However, lack of experimental replication precludes statistical evaluation of observed LL/HL differences in 


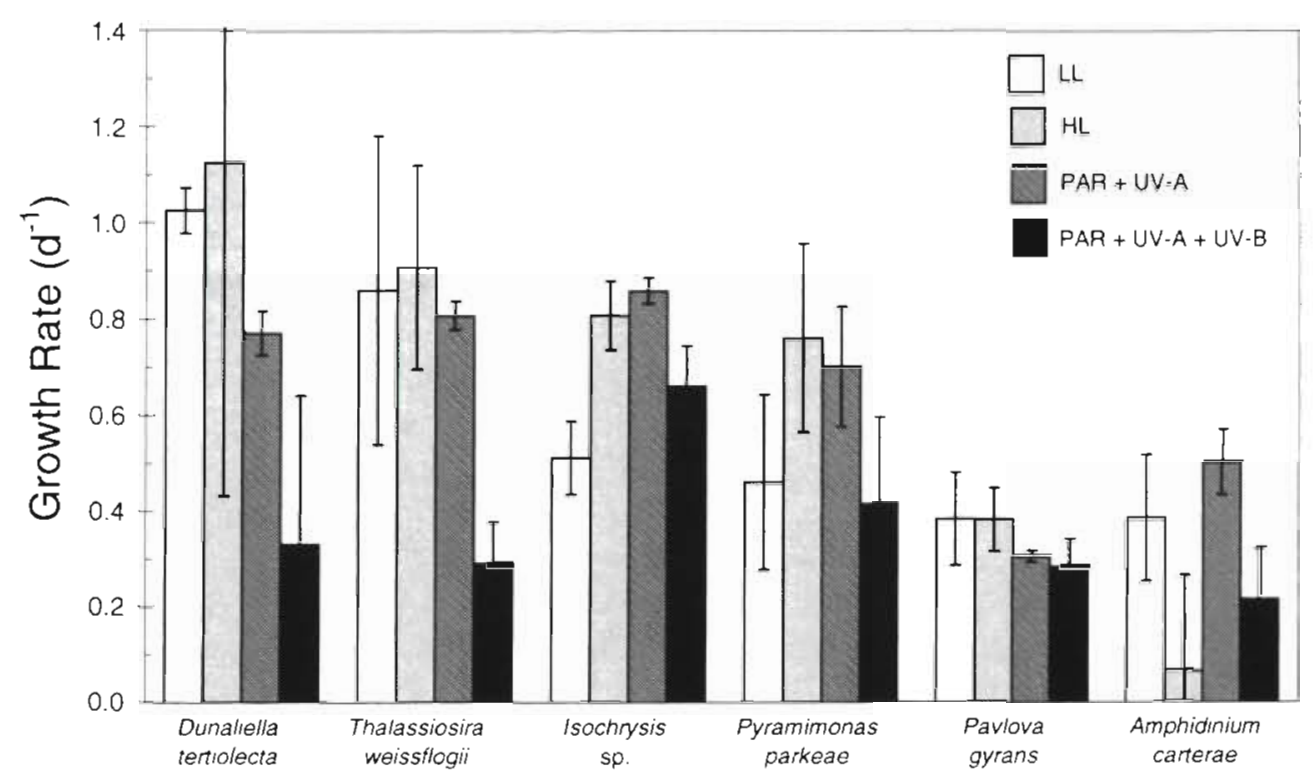

Fig. 1. Chl a-specific growth rates for 6 species cultured at low light (LL), high light (HL), PAR+UV-A, and PAR+UV-A+UV-B. $\mathrm{Chl}$ a was estimated from in vivo fluorescence after addition of DCMU. Rates were calculated by linear regression following ln transformation of chl a values obtained daily between the following days of exposure to LL or HL, PAR+UV-A, and PAR+UVA+UV-B, respectively: Dunaliella tertiolecta, 2-5, 0-3,0-3; Thalassiosira weissflogii, 1-4, 0-3, 0-3; Isochrysis sp , 4-7, 1-5, 4-7; Pyramimonas parkeae, 4-7, 1-4,4-7; Pavlova gyrans, 3-7,1-6, 1-6; Amphidinium carterae, 4-9, 1-5, 1-6. PAR-only cultures: error bar represents $95 \%$ confidence interval of regression coefficient (cultures were not replicated). UV-exposed cultures: error bar represents $95 \%$ confidence interval of the mean of 3 replicate cultures

growth, UV-B radiation at doses listed in Table 1 significantly affected the growth rates of all species except the prymnesiophyte Pavlova gyrans (Fig. 1, Tables 2 \& 3). Because initial trials with this species showed a strong inhibition of chl a-specific growth under weighted UV-B doses of 304 and $216 \mathrm{~mW} \mathrm{~m}^{-2}$ (1 and 2 layers of cellulose acetate, respectively), the UV-B dose was subsequently reduced to $103 \mathrm{~mW} \mathrm{~m}^{-2}$ by addition of 2 more layers of cellulose acetate. At this UV-B dose, P. gyrans exhibited a $7 \%$, non-significant decrease in the chl $a$-specific growth rate relative to the PAR+UV-A treatment. In Isochrysis sp. the

Table 2. Cell-specitic growth rates (d: mean $\pm \mathrm{SD}, \mathrm{n}=3$ ) determined for 3 of the 6 species in UV treatments (PAR+ UV-A, PAR+UV-A+UV-B). Numbers in parentheses indicate days after onset of UV exposure included in growth rate calculations. Irradiance levels as in Table 1

\begin{tabular}{|lcc|}
\hline Species & PAR+UV-A & PAR+UV-A+UV-B \\
\hline Isochrysis sp. & $0.787 \pm 0.048(1-5)$ & $0.141 \pm 0.022(1-4)$ \\
& & $0.688 \pm 0.101(4-7)$ \\
Pyramimonas & $0.672 \pm 0.054(1-4)$ & $0.083 \pm 0.264(1-3)$ \\
parkeae & & $0.414 \pm 0.116(3-6)$ \\
$\begin{array}{l}\text { Amphidinium } \\
\text { carterae }\end{array}$ & $0.606 \pm 0.033(1-5)$ & $0.293 \pm 0.009(1-6)$ \\
\hline
\end{tabular}

depression of growth by UV-B radiation was significant when expressed as chl a-specific but not when expressed as cell-specific. Upon exposure to UV-A+ UV-B radiation, Isochrysis sp. and P. parkeae had 3 to

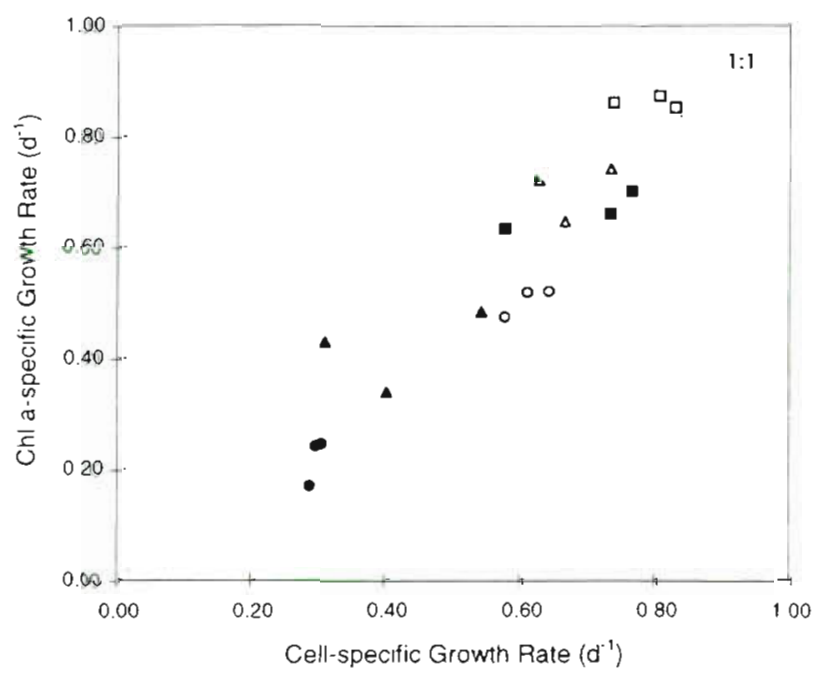

Fig. 2. Relationship between in vivo fluorescence based chl aspecific growth rate and cell-specific growth rate in UVexposed cultures of Isochrysis sp. (ロ, व), Pyramimonas parkeae $(\Lambda, \Delta)$, and Amphidinium carterae $(\bullet, 0)$. Open symbols, PAR + UV-A treatment; solid symbols, PAR+UV-A+UVB treatment 
Table 3. Effects of UV-B radiation on chl a-specific growth rate, cell-specific growth rate, cellular fluorescence capacity (CFC), cell volume, chl a-specific MAA concentration, and cell- and cell-volume-specific MAA concentration, expressed as percent change of the PAR+UV-A+UV-B treatment relative to the PAR+UV-A treatment. One-tailed probability values from Student's $t$-tests for comparison of treatment means in parentheses. ns: means not significantly different at $\alpha=0.05$. ND: no data

\begin{tabular}{|c|c|c|c|c|c|c|c|}
\hline \multirow[t]{2}{*}{ Species } & \multicolumn{2}{|c|}{ Growth rate } & \multirow[t]{2}{*}{$\mathrm{CFC}$} & \multirow[t]{2}{*}{ Cell volume } & \multicolumn{3}{|c|}{ MAA concentration ${ }^{a}$} \\
\hline & Chl a-specific & Cell-specific & & & perng chl a & per cell & per cell volume \\
\hline Dunaliella tertiolecta & $\begin{array}{c}-57 \% \\
(p=0.002)\end{array}$ & ND & $\begin{array}{c}-9.0 \% \\
\text { (ns) }\end{array}$ & ND & $\begin{array}{c}+51 \% \\
\text { (ns) }\end{array}$ & ND & ND \\
\hline Thalassiosira weissflogii & $\begin{array}{c}-64 \% \\
(p=0.000)\end{array}$ & ND & $\begin{array}{c}-5.6 \% \\
\text { (ns) }\end{array}$ & ND & $\begin{array}{c}-0.1 \% \\
\text { (ns) }\end{array}$ & ND & ND \\
\hline Isochrysis $\mathrm{sp}$. & $\begin{array}{c}-23 \% \\
(p=0.000)\end{array}$ & $\begin{array}{c}-13 \% \\
\text { (ns) }\end{array}$ & $\begin{array}{c}-4.1 \% \\
(p=0.010)\end{array}$ & $\begin{array}{c}+31 \% \\
(p=0.004)\end{array}$ & $\begin{array}{c}+141 \% \\
(p=0.011)\end{array}$ & $\begin{array}{c}+170 \% \\
(p=0.006)\end{array}$ & $\begin{array}{c}+105 \% \\
(p=0.031)\end{array}$ \\
\hline Pyramimonas parkeae & $\begin{array}{c}-41 \% \\
(p=0.003)\end{array}$ & $\begin{array}{c}-38 \% \\
(p=0.013)\end{array}$ & $\begin{array}{c}-17.4 \% \\
(p=0.033)\end{array}$ & $\begin{array}{c}+72 \% \\
(p=0.003)\end{array}$ & $\begin{array}{c}+95 \% \\
(\text { ns })^{b}\end{array}$ & $\begin{array}{c}+327 \% \\
(\mathrm{~ns})^{\mathrm{c}}\end{array}$ & $\begin{array}{c}+138 \% \\
\text { (ns) }^{\mathrm{d}}\end{array}$ \\
\hline \multirow[t]{3}{*}{ Pavlova gyrans } & $\begin{array}{c}-7 \% \\
\text { (ns) }\end{array}$ & ND & $\begin{array}{c}+3.5 \% \\
(p=0.022)\end{array}$ & ND & $\begin{array}{l}+23 \% \\
\text { (ns) }\end{array}$ & ND & ND \\
\hline & & & & ND & $\begin{array}{c}+1.0 \% \%^{\mathrm{e}} \\
\text { (ns) }\end{array}$ & ND & ND \\
\hline & & & & ND & $\begin{array}{c}+277 \% \\
(p=0.000)\end{array}$ & ND & ND \\
\hline Amphidinium carterae & $\begin{array}{c}-57 \% \\
(p=0.000)\end{array}$ & $\begin{array}{c}-52 \% \\
(p=0.000)\end{array}$ & $\begin{array}{c}-1.4 \% \\
\text { (ns) }\end{array}$ & $\begin{array}{c}+58 \% \\
(p=0.000)\end{array}$ & $\begin{array}{c}+0.7 \% \\
\text { (ns) }\end{array}$ & $\begin{array}{c}+183 \% \\
(p=0.009)\end{array}$ & $\begin{array}{c}+77 \% \\
(p=0.021)\end{array}$ \\
\hline \multicolumn{8}{|c|}{$\begin{array}{l}{ }^{a} \text { Mycosporine-glycine-like compound, except as indicated for } P \text {.gyrans } \\
{ }^{b}+159 \%(p=0.003) \text { if outlier is dropped (see text for details) } \\
c+467 \%(p=0.024) \text { if outlier is dropped } \\
{ }^{a}+206 \%(p=0.029) \text { if outlier is dropped } \\
\text { CCompound } 2 \text { (unknown) } \\
{ }^{t} \text { Compound } 3 \text { (shinorine/porphyra-334-like) }\end{array}$} \\
\hline
\end{tabular}

4 d initial lags in growth. The mean chl a-specific growth rate in Isochrysis sp. UV-B exposed cultures increased from $0.129 \mathrm{~d}^{-1}$ (Days 1 to 4 ) to $0.661 \mathrm{~d}^{-1}$ (Days 4 to 7 ), closely resembling the increase in cellspecific growth rates (Table 2 ), and reaching $77 \%$ and $87 \%$ of the chl $a$ - and cell-specific PAR+UV-A rates, respectively. $P$. parkeae $\mathrm{PAR}+\mathrm{UV}-\mathrm{A}+\mathrm{UV}-\mathrm{B}$-exposed cultures averaged no net chl a- or cell-specific growth during the first $3 \mathrm{~d}$ of exposure. After this time lag, cells partially recovered and their growth rate increased to 59 and $62 \%$ of the chl $a$ - and cell-specific PAR+UV-A rates, respectively.

Growth rates determined from in vivo fluorescence for Isochrysis $\mathrm{sp}$. and Pyramimonas parkeae UVexposed cultures were close $(3$ and $5 \%$ higher, respectively) to growth rates determined from cell counts, an indication that chl a fluorescence per cell remained stable during the exponential growth phase (Fig. 2, Tables $2 \& 3$ ). In contrast, growth rates determined from in vivo fluorescence for Amphidinium carterae UV-exposed cultures were consistently lower than, and averaged $78 \%$ of, growth rates determined from cell counts, possibly resulting from a gradual reduction of the chl a fluorescence per cell during the study period (Fig. 2).
Cell volumes, obtained by approximating the volume of a sphere, increased significantly with UV-B radiation in the 3 species examined (Table 3 ).

\section{Cellular fluorescence capacity}

The CFC index $\left(F_{\mathrm{v}} / F_{\mathrm{m}}\right)$ declined with UV-A and/or UV-A+UV-B exposure in all species except Pavlova $g y$ rans (Fig. 3). After $4 \mathrm{~d}$ of exposure, CFC was significantly depressed by UV-A radiation in Thalassiosira weissflogii (10\%) and Amphidinium carterae (10\%), and by UV$A+U V-B$ radiation in Dunaliella tertiolecta $(12 \%), T$. weissflogii (15\%), Isochrysis sp. (10\%), and A. carterae $(11 \%)$ (paired $t$-test, Table 4$)$. The large variability in CFC among Pyramimonas parkeae PAR+UV-A+UV-B replicates (range: 0.42 to 0.55 ) explains the lack of a significant UV-A+UV-B effect on Day 4 relative to Day 0 (Table 4). Nonetheless, CFC was significantly lower in $P$. parkeae cultures exposed to UV-A+UV-B than in those exposed to UV-A alone (Table 2), indicating a UV-B effect on CFC in this species as well. In addition to $P$. parkeae, only Isochrysis sp. had a significantly lower CFC index under UV-A+UV-B exposure than under UV-A exposure alone (Table 2). 


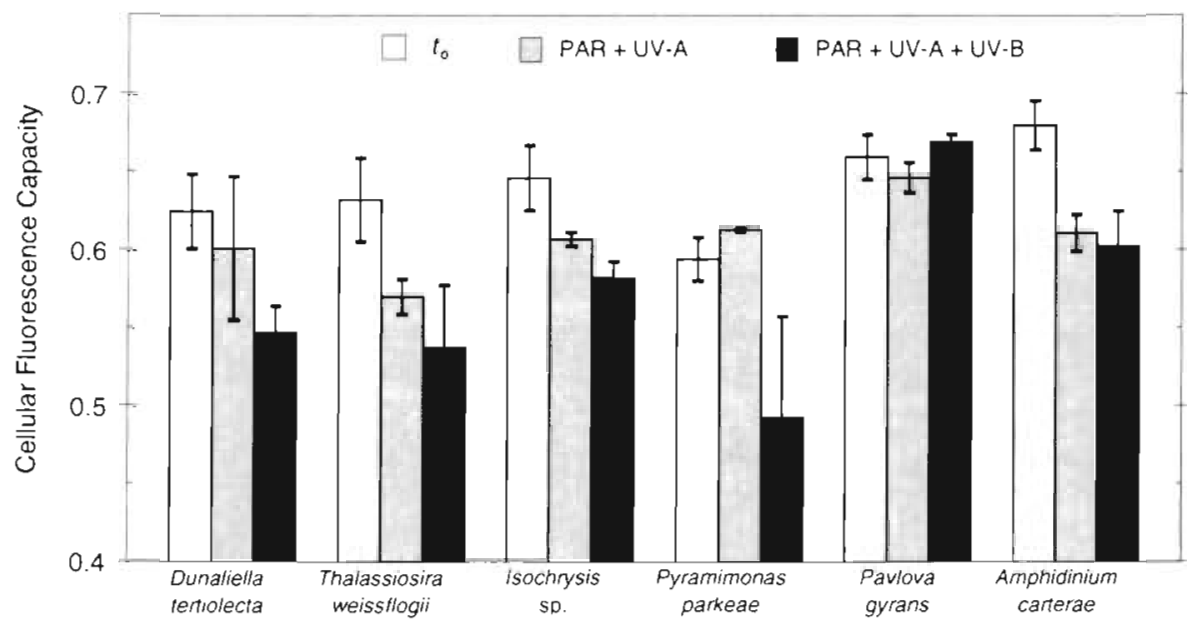

Fig. 3. Effects of UV radiation on CFC (cellular fluorescence capacity) calculated as $\left(F_{\mathrm{rn}}-F_{0}\right) / F_{\mathrm{m}}$ Mean $\pm \mathrm{SD}$ prior to $\left(t_{0}, \mathrm{n}=6\right)$ and after $3 \mathrm{~d}$ (Thalassiosira weissflogii) or $4 \mathrm{~d}$ (all other species) of UV exposure $(n=3)$. Significances of treatment effects are listed in Tables 3 \& 4

\section{In vivo absorption}

Pigment-specific spectral absorption coefficients for cultures exposed to LL, HL, PAR+UV-A, and PAR+ UV-A+UV-B are shown in Fig. 4 and total absorption in Fig. 5. In contrast with Pavlova gyrans, the other 5 species examined exhibited relatively small in vivo absorption peaks or shoulders with maxima ranging from 339 to $344 \mathrm{~nm}$ (Table 5). In Thalassiosira weissflogii, absorption spectra suggest that the compounds responsible for UV absorption were induced somewhat by high fluence PAR and by UV-A and UV-A+UV-B radiation. In Dunaliella tertiolecta, induction was restricted to high fluence PAR and UV-A radiation. Absorption spectra showed no evidence of high fluence PAR- or UV-induced production of UV-absorbing compounds in Isochrysis sp., Pyramimonas parkeae or Amphidinium carterae. On the other hand, P. gyrans exhibited a large increase in UV absorption following exposure to HL and UV radiation (Figs. 4 \& 5, Table 5), with maxima at $335-336 \mathrm{~nm}$. Absorption coefficients in

Table 4. Effects of UV-A and UV-A+UV-B radiation on CFC. One-tailed probability values from paired Student's $t$-tests for comparison of treatment means prior to $\left(t_{0}\right)$ and after 3 or $4 \mathrm{~d}$ of exposure to PAR+UV-A or PAR+UV-A+UV-B radiation. ns: means not significantly different at $\alpha=0.05$

\begin{tabular}{|lcc|}
\hline Species & $\begin{array}{c}t_{0} \text { vs } \\
\text { PAR+UV-A }\end{array}$ & $\begin{array}{c}t_{0} \mathrm{vs} \\
\text { PAR+UV-A+UV-B }\end{array}$ \\
\hline Dunaliella tertiolecta & $\mathrm{ns}$ & 0.037 \\
Thalassiosira weissflogii & 0.030 & 0.015 \\
Isochrysis sp. & $\mathrm{ns}$ & 0.020 \\
Pyramimonas parkeae & $\mathrm{ns}$ & $\mathrm{ns}$ \\
Pavlova gyrans & $\mathrm{ns}$ & $\mathrm{ns}$ \\
Amphidinium carterae & $0.014^{\mathrm{a}}$ & $0.000^{\mathrm{a}}$ \\
& & \\
aReduced PAR dose in UV treatments (see Table 1) & \\
\hline
\end{tabular}

this region were similar for $\mathrm{HL}$ and $\mathrm{PAR}+\mathrm{UV}-\mathrm{A}$ cultures, suggesting a limited role of UV-A radiation in the induction of UV-absorbing compounds in this species. UV-B-exposed cultures exhibited a 5- to 6-fold increase in UV absorption, greatly exceeding absorption by light-harvesting photosynthetic pigments.

In the UV-C region ( $<280 \mathrm{~nm}$ ) the spectra show absorption by proteins and nucleic acids at $260-270 \mathrm{~nm}$. In the visible region $(400-700 \mathrm{~nm})$ absorption spectra suggest treatment effects on levels of accessory photosynthetic pigments relative to chl $a$, but no major differences in pigment composition are apparent between treatments.

\section{Mycosporine-like amino acids}

In all species except Pavlova gyrans chromatography of methanol extracts yielded only 1 major peak (retention time $=4.9 \mathrm{~min}$ ). Based on the $313 \mathrm{~nm}: 340 \mathrm{~nm}$ ratio of peak areas and co-chromatography with a known sample of $P$. gyrans this compound was tentatively identified as mycosporine-glycine $\left(\lambda_{\max }=310 \mathrm{~nm}\right)$. Dunaliella tertiolecta, Pyramimonas parkeae, Isochrysis sp. and Amphidinium carterae frequently exhibited a small shoulder (retention time $=5.0$ to $5.1 \mathrm{~min}$ ) on this peak, possibly caused by overlap with a related compound. In addition, a very small, unidentified peak $(<1.5 \%$ of total peak area) with a retention time of 6.7 min was present in $P$. parkeae and Isochrysis sp. $P$. gyrans chromatograms typically exhibited 3 major peaks (Fig. 6) with $313 \mathrm{~nm}: 340 \mathrm{~nm}$ peak area ratios of $1.2,1.6$, and 0.6 . Compound 1 has been tentatively identified as mycosporine-glycine, compound 2 is an unknown with absorption in the UV-B range, and compound 3 most likely corresponds to shinorine or porphyra-334 $\left(\lambda_{\max }=334 \mathrm{~nm}\right)$. The concentrations presented are based on HPLC peak areas (relative units) 
Fig. 4. Pigment-specific spectral absorption coefficients ( $a^{\circ}$ $\mathrm{m}^{2} \mathrm{mg}^{-1}$ chl a) for 6 species cultured at low light (LL), high light (HL), PAR+UV-A, and PAR+UV-A+UV-B. Spectra shown are the means of 2 duplicate samples per culture (LL, HL) or single samples from 3 replicate cultures (PAR+ UV-A, PAR+UV-A+UV-B)
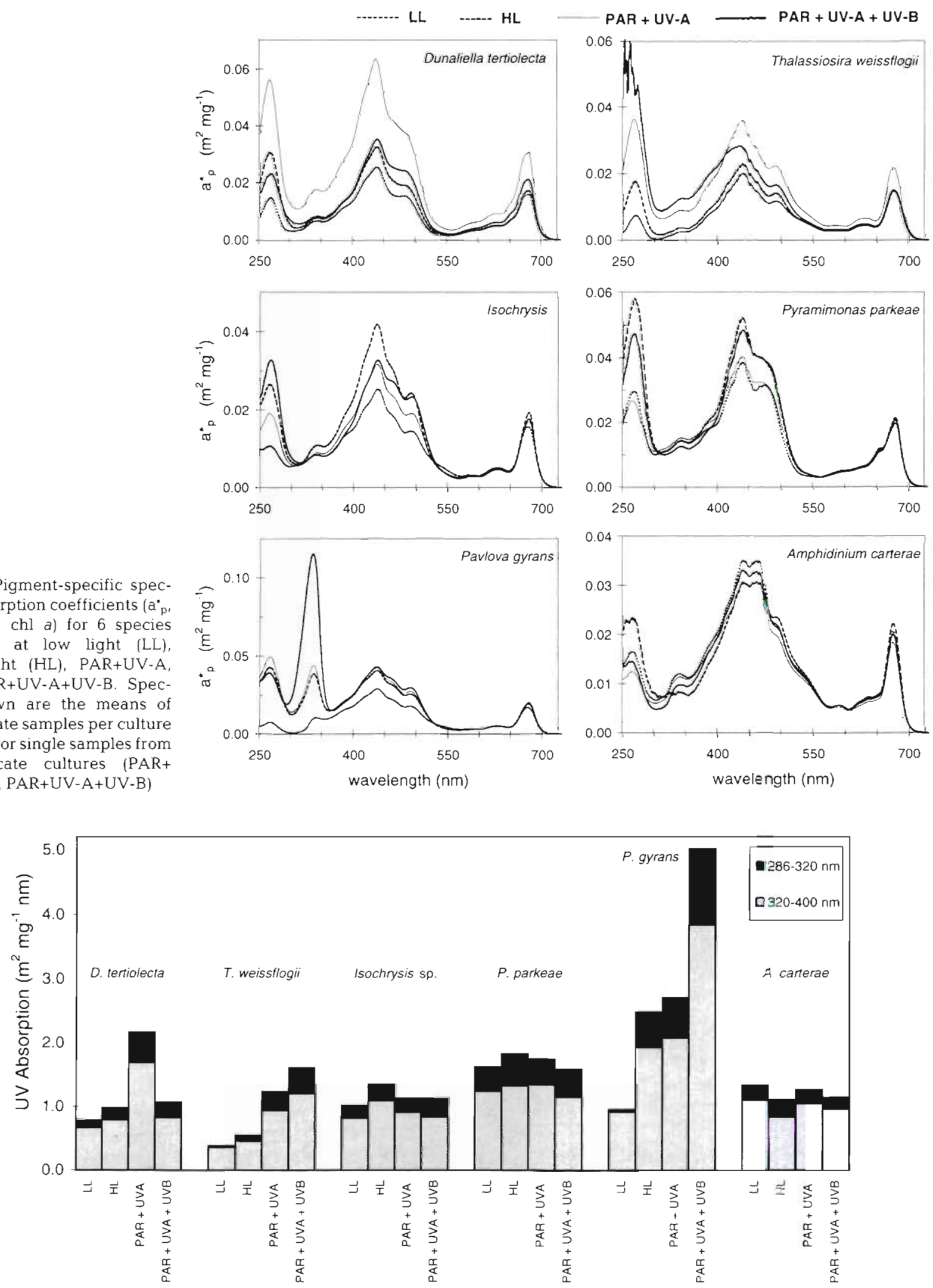

Fig. 5. Total chl a-specific in vivo absorption at UV-A (320-400 nm) and UV-B (286-320 nm) wavelengths, obtained by integration of the spectra shown in Fig. 4 
Table 5. Wavelength of in vivo UV absorption maximum and ratio of the mean chl a-specific absorption coefficients at maxima

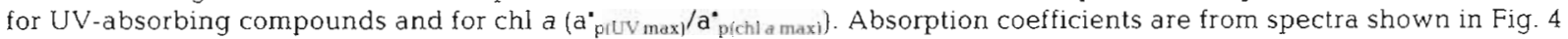

\begin{tabular}{|c|c|c|c|}
\hline Species & Treatment & $\begin{array}{l}\text { UV maximum } \\
(\mathrm{nm})\end{array}$ & 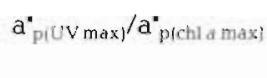 \\
\hline Dunaliella tertiolecta & $\begin{array}{l}\text { LL } \\
\text { HL } \\
\text { PAR+UV-A } \\
\text { PAR+UV-A+UV-B }\end{array}$ & $\begin{array}{l}343 \\
343 \\
342 \\
342\end{array}$ & $\begin{array}{l}0.42 \\
0.45 \\
0.58 \\
0.40\end{array}$ \\
\hline Thalassiosira weissflogii & $\begin{array}{l}\mathrm{LL} \\
\mathrm{HL} \\
\text { PAR+UV-A } \\
\text { PAR+UV-A+UV-B }\end{array}$ & $\begin{array}{l}345 \\
344 \\
340 \\
344\end{array}$ & $\begin{array}{l}0.17 \\
0.25 \\
0.41 \\
0.84\end{array}$ \\
\hline Isochrysis sp. & $\begin{array}{l}\text { LL } \\
\text { HL } \\
\text { PAR+UV-A } \\
\text { PAR+UV-A+UV-B }\end{array}$ & $\begin{array}{l}341 \\
342 \\
342 \\
342\end{array}$ & $\begin{array}{l}0.55 \\
0.57 \\
0.53 \\
0.48\end{array}$ \\
\hline Pyramimonas parkeae & $\begin{array}{l}\mathrm{LL} \\
\mathrm{HL} \\
\mathrm{PAR}+U V-A \\
\text { PAR+UV-A+UV-B }\end{array}$ & $\begin{array}{l}340 \\
342 \\
340 \\
343\end{array}$ & $\begin{array}{l}0.72 \\
0.68 \\
0.77 \\
0.61\end{array}$ \\
\hline Pavlova gyrans & $\begin{array}{l}\mathrm{LL} \\
\mathrm{HL} \\
\mathrm{PAR}+\mathrm{UV}-\mathrm{A} \\
\mathrm{PAR}+\mathrm{UV}-\mathrm{A}+\mathrm{UV}-\mathrm{B}\end{array}$ & $\begin{array}{l}340 \\
336 \\
336 \\
335\end{array}$ & $\begin{array}{l}0.61 \\
1.99 \\
2.14 \\
5.76\end{array}$ \\
\hline Amphidinium carterae & $\begin{array}{l}\text { LL. } \\
\text { HL } \\
\text { PAR+UV-A } \\
\text { PAR+UV-A+UV-B }\end{array}$ & $\begin{array}{l}341 \\
341 \\
340 \\
339\end{array}$ & $\begin{array}{l}0.59 \\
0.37 \\
0.62 \\
0.49\end{array}$ \\
\hline
\end{tabular}

detected at $313 \mathrm{~nm}$ or $340 \mathrm{~nm}$; the choice was determined by the $313 \mathrm{~nm}: 340 \mathrm{~nm}$ peak area ratio, $>1$ or $<1$, respectively. Peak integration included the shoulder when present. As peak areas are commonly used to derive concentrations when the response factors for the compounds are known, the relative concentrations presented here allow for direct quantitative comparisons between treatments, but not between compounds.

Transfer from LL tó $\mathrm{HL}$ caused a small increase in the concentration of MAAs in Thalassiosira weissflogii $(44 \%)$ and Pyramimonas parkeae $(9 \%$; Fig. 7). In the dinoflagellate, Amphidinium carterae, HL caused a 6 fold increase in the chl a-specific concentration of this compound. However, since there was evident bleaching of $A$. carterae cultures in HL, chl a degradation and not an increase in the cellular MAA concentration most likely explains the large increase in the chl a-based estimate of MAA content in this species. Dunaliella tertiolecta and Isochrysis sp. did not increase their MAA content in $\mathrm{HL}$.

Exposure to UV radiation-UV-A alone or in combination with UV-B - generally caused a small to moderate increase in the relative chl a-specific concentration of the mycosporine-glycine-like compound (Fig. 7). In Thalassiosira weissflogii, Pyramimonas parkeae, and
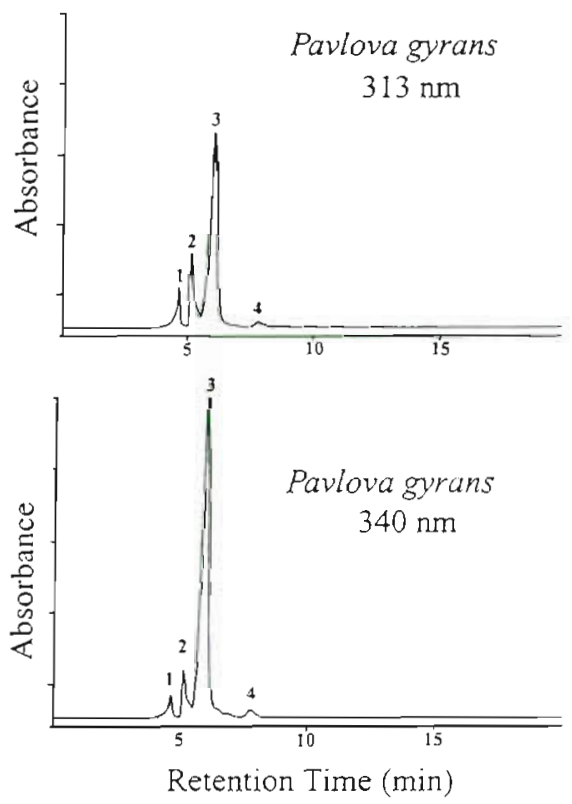

Fig. 6. HPLC chromatograms of mycosporine-lıke amino acids from methanol extracts of Pavlova gyrans grown under PAR $+U V-A$. The compounds are (1) mycosporine-glycine-like compound (retention time, $R T=4.6 \mathrm{~min}$ ), (2) unknown ( $R T=$ 5.1 min). (3) shinorine/porphyra-334-like compound (RT = $6.0 \mathrm{~min}$ ), and (4) unknown (RT $=7.7 \mathrm{~min}$ ). Both $313 \mathrm{~nm}$ (top) and $340 \mathrm{~nm}$ (bottom) chromatograms are the same scale 
Fig. 7. Relative chl a-specific concentration of the predominant MAA, a mycosporine-glycine-like compound, for 5 species cultured at low light (LL), high light (HL), PAR+UV-A, and PAR+UV-A+UVB. Mean and SD of 2 duplicate samples (LL, HL) or 3 replicate cultures (PAR+UV-A, PAR+UV-A+ UV-B). Absorbance detection at $313 \mathrm{~nm}$

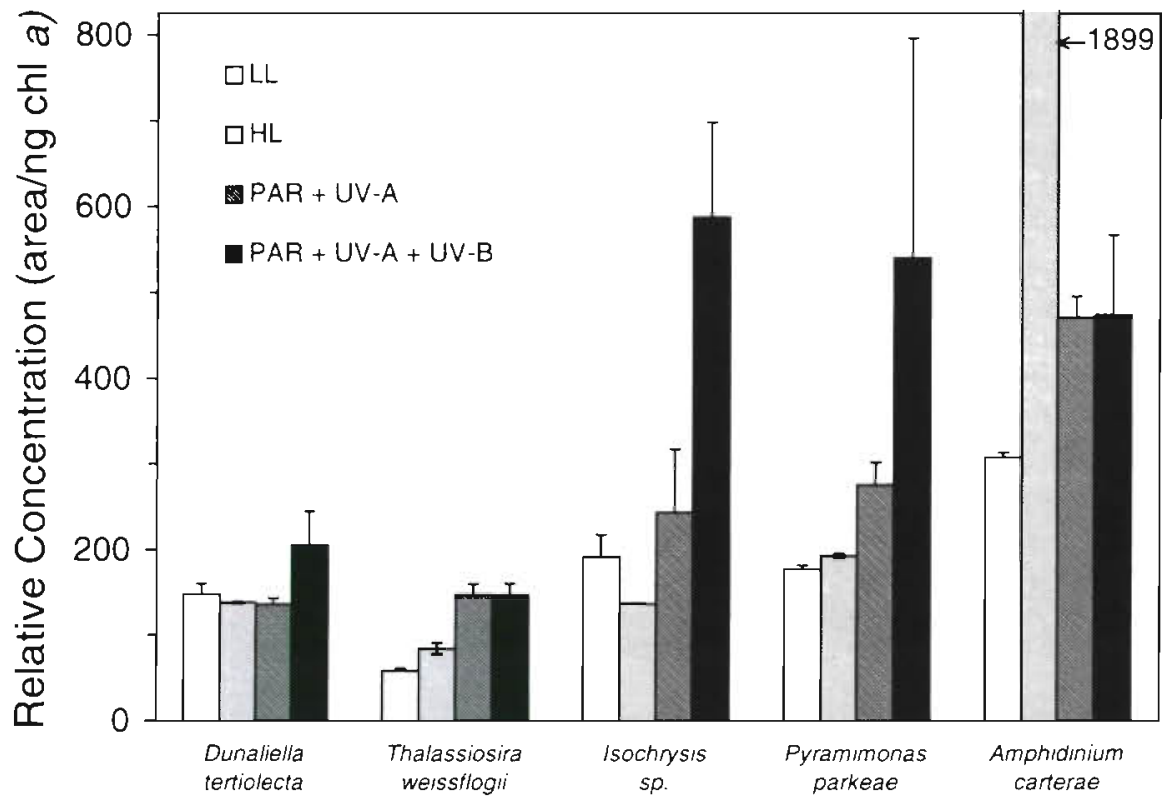

Isochrysis $\mathrm{sp}$., the average chl a-specific concentration of the mycosporine-glycine-like compound was 73,43 , and $77 \%$ higher, respectively, in UV-A-exposed than in PAR-only HL cultures. No effect of UV-A on this quantity was observed for Dunaliella tertiolecta. Because Amphidinium carterae in UV treatments received a PAR dose that was intermediate between LL and $\mathrm{HL}$ (see Table 1), the $53 \%$ increase observed between LL and UV-A-exposed cultures (Fig. 7) can at least in part be attributed to the higher PAR dose, and the UV-A effect alone cannot be determined from the data.

UV-A+UV-B radiation more effectively induced MAAs in some species than UV-A radiation alone. UV-B supplementation increased the average chl aspecific concentration of the mycosporine-glycine-like compound by 141 and $95 \%$ in Isochrysis sp. and Pyramimonas parkeae, respectively, relative to $\mathrm{PAR}+\mathrm{UV}-\mathrm{A}$ cultures (Table 3). The large standard deviation associated with the PAR+UV-A+UV-B treatment of $P$. parkeae (Fig. 7) is due to an unexpectedly high chl a concentration in one of the replicate cultures. The remaining 2 cultures averaged a concentration of $716 \pm$ 103 (relative units $\mathrm{ng}^{-1} \mathrm{chl}$ a), representing a highly significant $(p=0.003), 159 \%$ increase relative to the UV-A treatment. In Thalassiosira weissflogii, Pavlova gyrans and Amphidinium carterae, by contrast, the chl a-specific concentration of this MAA was not increased further by irradiation with UV-B, and in Dunaliella tertiolecta it increased by a non-significant $51 \%$. On a cell volume basis (Table 3), UV-B supplementation approximately doubled the MAA concentration in Isochrysis sp., P. parkeae and A. carterae. In $P$. gyrans large increases in the concentration of compound 3 were obtained with high fluence PAR and with UV-B supplementation, but UV-A radiation alone had a negligible effect (Fig. 8, Table 3).

The relationship between the UV absorption coefficient $\left(\mathrm{a}_{\mathrm{p}(\mathrm{UV} \max )}\right)$ and the relative concentration of
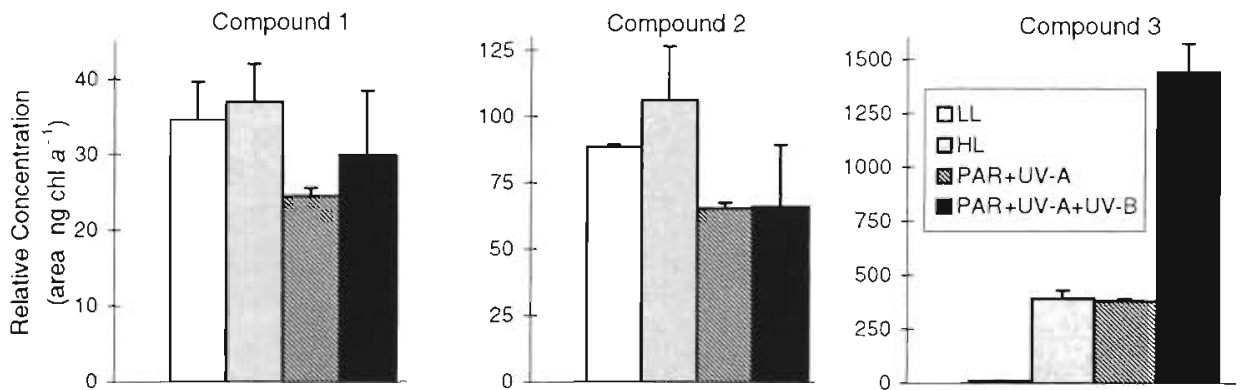

Fig. 8. Relative chl a-specific concentrations of mycosporine-like compounds in Pavlova gyrans cultured at low light (LL), high light (HL), PAR+UV-A, and PAR+UV-A+UV-B. Mean and SD of 2 duplicate samples (LL, HL) or 3 replicate cultures (PAR+UV-A, PAR+UV-A+UV-B). Absorbance detection at $313 \mathrm{~nm}$ (compounds 1 and 2) or $340 \mathrm{~nm}$ (compound 3). For compound identification see Fig. 6 
MAAs was analyzed collectively for all species by linear regression (data not shown). As both of these parameters are expressed on a chl a basis the relationship is independent of the pigment concentration. There was a very weak, yet significant positive correlation between the 2 variables $\left(\mathrm{R}^{2}=0.25, \mathrm{p}=0.014, \mathrm{n}=24\right)$. Only for Pavlova gyrans did a ${ }_{\text {pivv max }}$ clearly increase as a function of MAA concentration.

\section{DISCUSSION}

\section{Growth and sensitivity to UV radiation}

The inhibition of chl a-specific growth by UV radiation may result from photoinhibition of photosynthesis, assimilatory processes, and/or direct effects on cellular DNA. We measured a depression in the quantum yield of PS II fluorescence by UV-A or UV-A+UV-B radiation in 5 of the 6 species examined, as expected from UVinduced damage to PS II (Renger et al. 1989). Degradation of the D1 $32-\mathrm{kDa}$ protein complex within PS II is mediated by oxidative stress (Richter et al. 1990). This complex is one of many targets responsible for UV-B inhibition of photosynthesis (Franklin \& Forster 1997). UV-B was shown to inhibit the major $\mathrm{CO}_{2}$ fixing enzyme, Rubisco (Strid et al. 1990, Lesser 1996). A depression of nitrogen uptake and assimilation (Döhler 1985) as well as reduced rates of DNA synthesis (Buma et al. 1996) with exposure to UV-B have been reported for various microalgae. Impairment of any or all of these functions are likely to result in growth inhibition.

From the UV-B doses delivered and the depressions in chl a-specific growth we calculated an index of UV-B sensitivity (Behrenfeld et al. 1992) yielding the following rating in UV-B resistance: Pavlova gyrans $\geq$ Isochrysis sp. $>$ Dunaliella tertiolecta $\geq$ Pyramimonas parkeae > Thalassiosira weissflogii > Amphidinium carterae. This rating assumes a linear dose-response relationship and suggests highest resistance for the 2 prymnesiophytes. However, the location of P. gyrans in this ranking is uncertain since the low UV-B dose provided was based on initial trals which indicated that this species was highly susceptible to the higher UV-B doses. In comparison, the dinoflagellate Prorocentrum micans suffered a $32 \%$ depression in chl a-specific growth rate when grown with a total daily UV dose roughly one half of our lowest UV treatment (Lesser 1996), indicating that it is more sensitive to UV-B radiation than any of the species in the present study.

Based on evidence of a strong correlation between light-saturated photosynthetic rate and DCMU enhancement of fluorescence (Samuelsson \& Oquist 1977, Falkowski \& Kiefer 1985), we analyzed the relationship between growth rate depression and the decline in $F_{\mathrm{v}} / F_{\mathrm{m}}$ following exposure to UV-B. Correlation analysis, however, yielded a very weak positive association $(r=0.40)$ between these 2 parameters (columns 2 and 4 in Table 3 ). This can be explained by the co-occurrence of multiple UV-B-induced changes in cell metabolism that determine the extent of growth inhibition. At one extreme, Amphidinium carterae experienced a $57 \%$ reduction in the chl a-specific growth rate yet only a $1.4 \%$, non-significant reduction in $F_{\mathrm{v}} / F_{\mathrm{m}}$, suggesting that for this species it is not PS II, but other UV-B-sensitive cellular targets (e.g. Rubisco, DNA, membranes) that determine performance under UV-B stress. Similarly, the $30 \%$ UV-B-induced reduction in growth experienced by the dinoflagellate Prorocentrum micans was not accompanied by a significant drop in $F_{\mathrm{v}} / F_{\mathrm{m}}$ (Lesser 1996). At the other extreme is Pyramimonas parkeae, which for a $41 \%$ decrease in chl a-specific growth had a correspondingly high $17.4 \%$ decrease in $F_{\mathrm{v}} / F_{\mathrm{m}}$, suggesting that, for this species, reduction in $F_{\mathrm{v}} / F_{\mathrm{m}}$ can explain a significant portion of the UV-B-induced inhibition of growth.

The growth patterns observed following exposure to UV-B radiation suggest that Isochrysis sp., Pyramimonas parkeae, and possibly Pavlova gyrans underwent a period of UV-B acclimation. Lags in growth lasted a few days and were followed by partial recovery. Lesser et al. (1994) point out that acclimation to UV establishes a new equilibrium between damage and repair processes. The initial lag in growth observed in these species seems to indicate differential cell death or activation of repair mechanisms requiring protein synthesis (Ohad et al. 1984, Lesser et al. 1994). However, some repair activation rates may be too rapid to explain an acclimation period lasting several days. In Thalassiosira pseudonana, for example, cumulative carbon uptake reaches an equilibrium between damage and repair 30 to $60 \mathrm{~min}$ after exposure to UV-B (Lesser et al. 1994). A period of acclimation to UV radiation was not apparent in our cultures of Dunaliella tertiolecta, $T$. weissflogii, or Amphidinium carterae. Similarly, Jokiel \& York (1984) found no evidence of photoadaptation in $14 \mathrm{~d}$ exposures of phytoplankton to solar UV-B radiation. In $30 \mathrm{~d}$ outdoor growth experiments with the temperate estuarine diatom Phaeodactylum tricornutum, Behrenfeld et al. (1992) instead observed an increase in UV-B sensitivity with time. The authors ascribed this to a progressive decrease in photorepair capabilities associated with a decline in ambient photorepair wavelengths.

Variations in cell size are considered significant in photoprotection since increased cell volume would protect sensitive sites, particularly centrally located DNA, by increasing the pathlength of light travelling through the cell (Garcia-Pichel 1994). The absorption of UV by various cellular constituents, including any 
selectively UV-absorbing compounds, would thus afford greater protection to the nucleus of larger cells. Of the species used in this study, Amphidinium carterae, Thalassiosira weissflogii, and Pyramimonas parkeae are relatively large-celled (average diameters $\geq 10 \mu \mathrm{m})$, followed by Dunaliella tertiolecta, Pavlova gyrans, and Isochrysis sp., with average cell diameters of $8.1,5.6$, and $4.5 \mu \mathrm{m}$, respectively. Contrary to expectations, the comparison of cell size with their relative sensitivities to UV-B radiation - a ranking based on growth inhibition (see above)-suggests greater UV-B resistance for the smaller-celled than for the larger-celled species in this study. In contrast, a comparison of DNA damage and repair in 12 Antarctic diatom species (Karentz et al. 1991a) indicated higher sensitivity to UV exposure in the smaller-celled species. Furthermore, Bothwell et al. (1993) found that attached diatom communities exposed to ambient UV radiation for a prolonged period of time attained significantly greater mean cell sizes than communities not exposed to UV, and that this change resulted from a shift to larger-celled species.

The cell volumes of Isochrysis sp., Pyramimonas parkeae, and Amphidinium carterae were found to increase by ca 30,70 , and $60 \%$, respectively, with exposure to UV-B radiation, in agreement with observations for Phaeodactylum tricornutum by Behrenfeld et al. (1992). These presumably phenotypic changes in cell size may be a photoprotective response, or alternatively, the result of UV-inhibited cell division. Karentz et al. (1991a) report that the size of UV-B-and UV-Cirradiated Antarctic diatoms greatly increased in some species due to arrested cell division. Alterations in cell volume also were reported as a response to shifts in PAR intensity (Thompson et al. 1991).

\section{UV-absorbing compounds}

The major mycosporine-like compound extracted from the 5 species other than Pavlova gyrans was tentatively identified as mycosporine-glycine, a compound with an absorption maximum in the UV-B range (Nakamura et al. 1982). While we were not able to quantify its cellular content, it is apparent that this compound was present in very small amounts relative to $\mathrm{chl}$ a. In vivo spectral absorption coefficients at UV maxima were on the order of 0.003 to $0.018 \mathrm{~m}^{2} \mathrm{mg}^{-1} \mathrm{chl}$ a for our 5 species with low UV absorption. As can be appreciated from the whole cell absorption spectra (Fig. 4) and the spectra of crude methanol extracts (not shown), the UV absorbance peak for these 5 species is small and broad, and shifted to longer, UV-A wavelengths. This is most likely the result of spectral overlap with pigments from photosynthetic antenna, which can absorb down to
$300 \mathrm{~nm}$ (Vernet et al. 1989), at one end, and absorption by proteins and nucleic acids at the opposite end of the spectrum. The dominant compound in P. gyrans corresponds to a MAA with maximum absorbance in the UV-A range. A compound with maximum absorbance in the UV-A range also was identified as a quantitatively important MAA in the Antarctic prymnesiophyte Phaeocystis sp. (Bidigare et al. 1996).

Our results indicate that the ability of phytoplankton to produce significant amounts of MAAs through photoinduction may be limited to certain species or taxa. Taxonomic composition appeared to be one of the most important factors in controlling UV absorption in Antarctic phytoplankton (Vernet et al. 1994), as prymnesiophyte-dominated populations typically exhibited enhanced UV absorption. The species with pronounced and inducible UV absorption used here, Pavlova gyrans, is also a prymnesiophyte, as is the widespread and bloom-forming Phaeocystis pouchetii, shown to contain large amounts of UV-absorbing compounds (Marchant et al. 1991). The presence of MAAs in all cultures raises the question whether these compounds may have a role in the biochemistry of the cell unrelated to UV protection.

High fluence PAR (255-290 $\mu \mathrm{mol}$ photons $\mathrm{m}^{-2} \mathrm{~s}^{-1}$ ) did not induce production of UV-absorbing compounds in all the species examined, but they all exhibited some, albeit mostly small, degree of induction in response to UV-A or UV-B radiation. Small increases in MAA content with HL were observed for Thalassiosira weissflogii and Pyramimonas parkeae, and a very pronounced increase was evident for Pavlova gyrans. Under similar conditions, Carreto et al. (1990a) transferred the dinoflagellate Alexandrium excavatum from 20 to $200 \mu \mathrm{mol}$ photons $\mathrm{m}^{-2} \mathrm{~s}^{-1}$ and obtained a severalfold increase in UV absorption after only $3 \mathrm{~h}$. Both absorption spectra and HPLC analyses revealed that UV-absorbing compounds were present in all LL cultures. It is therefore possible that most of our LL treatments were not sufficiently light-limited to reduce MAA production to levels appreciably lower than under bright light. In fact, PFDs delivered to LL cultures proved growth-limiting for only 2 species, Isochrysis sp. and $P$. parkeae; both these cultures received the lower PAR dose supplied in Expt $C$, 25-33 $\mu \mathrm{mol}$ photons $\mathrm{m}^{-2} \mathrm{~s}^{-1}$.

The highest reported relative concentration of UVabsorbing compounds was that for the Antarctic colonial prymnesiophyte Phaeocystis pouchetii, with an extract UV:chl a absorbance ratio of 27 (Davidson \& Marchant 1994). Colonial Phaeocystis sp. increased its concentration of UV-absorbing compounds with increasing UV-B radiation, although its UV absorbance was high even when not recently exposed to UV radiation (Marchant et al. 1991). Our results with Pavlova 
gyrans indicate that it contains very low concentrations of UV-absorbing, mycosporine-like compounds until exposed to bright visible light or UV radiation. A 10 fold increase in the maximum PFD induced a 39 -fold increase in 1 of the 3 MAA compounds, and this increase was accompanied by an almost 4-fold increase in the UV spectral absorption coefficient. When exposed to UV-A+UV-B radiation, there was a 145-fold increase in MAAs, accompanied by an 11 -fold increase in the UV spectral absorption coefficient, relative to LL. Our maximum values for the UV spectral absorption coefficient of $P$. gyrans, $0.12 \mathrm{~m}^{2} \mathrm{mg}^{-1} \mathrm{chl} \mathrm{a}_{\text {, }}$ compare well with values by Neale \& Spector (1994) from a Thalassiosira gravida spring bloom in Antarctica that had maximum UV spectral absorption coefficients in the range $0.05-0.11 \mathrm{~m}^{2} \mathrm{mg}^{-1} \mathrm{chl} a$.

The PAR dependency of MAA production in Pavlova gyrans may reflect MAA synthesis that is dependent on photosynthetic activity, possibly enabling the biosynthesis of precursors (Carreto et al. 1990b). When cultures were subsequently exposed to UV-A radiation their MAA content did not increase further, contrary to expectations based on results from studies with Alexandrium excavatum (Carreto et al. 1990b) and Phaeocystis sp. (Bidigare et al. 1996). Cells transferred from the HL culture to the PAR+UV-A and PAR+ $U V-A+U V-B$ treatments experienced a small reduction in PAR intensity $(<10 \%$; however, this estimate is based on different light sensors) associated with the lower transmissivity of teflon relative to borosilicate glass. If this drop in PAR intensity effectively lowered the rate of MAA production, then a relatively small stimulating effect of UV-A radiation on MAA production could have remained undetected.

Whole-cell absorption spectra yield very limited information regarding the identity of the compounds responsible for UV absorption. The 5 species that exhibited limited induction capabilities predominantly contained a compound with maximum absorption in the UV-B range. In these species, however, in vivo UV absorption maxima were shifted to longer, UV-A wavelengths, and centered around 339-345 nm. On the other hand, the one species that proved highly inducible, Pavlova gyrans, contained predominantly a compound with maximum absorption in the UV-A range. In vivo UV absorption maxima in this species were centered around $340 \mathrm{~nm}$ when grown under LL and MAAs were present in small amounts, but shifted to shorter wavelengths in $\mathrm{HL}$ - and UV-induced cultures, more closely reflecting the absorption maximum of the predominant MAA. These observations are based on absorption spectra already corrected for nonextractable cell material, such as membranes or cellular coverings. In addition, absorption by DNA, proteins, and photosynthetic pigments are superimposed on the absorption by MAAs or any other selective UV absorbers. Our data suggest that photosynthetic pigments spectrally overlap with the selective UV absorbers, resulting in a pronounced shift of UV absorption maxima at low concentrations. Deconvolution of the in vivo absorption spectra will be required to resolve pigment overlap and predict the contribution of the MAA fraction to total absorption in the UV range, a technique that has been applied to whole cell absorption of visible light in phytoplankton (Bidigare et al. 1989).

In summary, results from these acclimation experiments demonstrate that UV stress elicits responses that are species-specific. Our measurements of growth and photochemical capacity agree with other studies (e.g. Cullen \& Neale 1994) in supporting the prediction that there is an important differential sensitivity to UV-B radiation among phytoplankton species, and that this could lead to significant changes in the species composition of a natural assemblage. Based on the depression in growth and photochemical capacity the 6 species that we examined differed in their degree of UV-B resistance, with the 2 prymnesiophytes exhibiting the highest and the dinoflagellate the lowest resistance. The 6 species also differed in the photoinducibility of UV-absorbing compounds, as only the prymnesiophyte Palova gyrans exhibited a pronounced MAA synthesis response to irradiance.

Acknowledgements. We thank P. Neale for providing the Biological Weighting Function, J. Chapman for providing the solar scans, A. Banaszak for advice on. MAA chromatography, and $M$. Vernet and $R$. Steele for early reviews of the manuscript. This research was supported by a National Research Council Associateship to G.H. by the Environmental Protection Agency. This document was subjected to the Agency's peer and administrative review, and it was approved for publication as an EPA document. Mention of trade names or commercial products does not constitute endorsement or recommendation for use.

\section{LITERATURE CITED}

Adams NL, Shick JM (1996) Mycosporine-like amino acids provide protection against ultraviolet radiation in eggs of the green sea urchin Strongylocentrotus droebachiensis. Photochem Photobiol 64:149-158

Banaszak AT, Trench RK (1995) Effects of ultraviolet (UV) radiation on marine microalgal-invertebrate symbioses. II. The synthesis of mycosporine-like amino acids in response to exposure to UV in Anthopleura elegantissima and Cassiopeia xamachana. J Exp Mar Biol Ecol 194:233-250

Behrenfeld MJ, Hardy JT, Lee H II (1992) Chronic effects of ultraviolet-B radiation on growth and cell volume of Phaeodactylum tricornutum (Bacillariophyceae). J Phycol 28:757-760

Behrenfeld MJ, Lee H II, Small LF (1994) Interactions between nutritional status and long-term responses to ultraviolet-B radiation stress in a marine diatom. Mar Biol 11.8:523-530 
Bidigare RR, Iriarte JL, Kang SH, Ondrusek ME, Karentz D, Fryxell GA (1996) Phytoplankton: quantitative and qualitative assessments. In: Ross RM, Hofmann EE, Quetin LB (eds) Foundations for ecological research west of the Antarctic Peninsula. Antarctic Research Series, Vol 70, American Geophysical Union, Washington, DC, p 173-197

Bidigare RR, Morrow JH, Kiefer DA (1989) Derivative analysis of spectral absorption by photosynthetic pigments in the western Sargasso Sea. J Mar Res 47:323-341

Bothwell ML, Sherbot DMJ, Roberge AC, Daley RJ (1993) Influence of natural ultraviolet radiation on lotic periphytic diatom community growth, biomass accrual, and species composition: short-term versus long-term effects. J Phycol 29:24-35

Buma GJA, Van Hannen EJ, Veldhuis MJW, Gieskes WWC (1996) UV-B induces DNA damage and DNA synthesis delay in the marine diatom Cyclotella sp. Sci Mar 60 (Suppl 1):101-106

Caldwell MM, Robberecht R, Flint SD (1983) Internal filters: prospects for UV-acclimation in higher plants. Physiol Plant 58:445-450

Carreto JI, Carigan MO, Daleo G, DeMarco SG (1990a) Occurrence of mycosporine-like amino acids in the redtide dinoflagellate Alexandrium excavatum: UV-protective compounds? J Plankton Res 12:909-921

Carreto JI, Lutz VA, DeMarco SG, Carignan MO (1990b) Fluence and wavelength dependence of mycosporine-like amino acid synthesis in the dinoflagellate Alexandrium excavatum. In: Graneli E, Edler L, Sundstrom B, Anderson AD (eds) Toxic marine phytoplankton. Elsevier, New York, p $275-279$

Crutzen PJ (1992) Ultraviolet on the increase. Nature 356: $104-105$

Cullen JJ, Neale PJ (1994) Ultraviolet radiation, ozone depletion, and marine photosynthesis. Photosynth Res 39: $303-320$

Cullen JJ, Neale PJ, Lesser MP (1992) Biological weighting function for the inhibition of phytoplankton photosynthesis by ultraviolet radiation. Science 258:646-650

Davidson AT, Bramich D. Marchant HJ, McMinn A (1994) Effects of UV-B irradiation on growth and survival of Antarctic marine diatoms. Mar Biol 119.507-515

Davidson AT, Marchant HJ (1994) The impact of ultraviolet radiation on Phaeocystis and selected species of Antarctic marine diatoms. In: Weiler CS, Penhale PA (eds) Ultraviolet radiation in Antarctica: measurements and biological effects. Antarct Res Ser 62:187-205

Döhler G (1985) Effect of UV-B radiation (290-320 nm) on the nitrogen metabolism of several marine diatoms. J Plant Physiol 118:391-400

Dunlap WC, Chalker BE (1986) Identification and quantitation of near-UV absorbing compounds (S-320) in a hermatypic scleractinian. Coral Reefs 5:155-159

Dunlap WC, Chalker BE, Oliver JK (1986) Bathymetric adaptations of reef-building corals at Davies Reef, Great Barrier Reef, Australia. Ill. UV-B absorbing compounds. $J$ Exp Mar Biol Ecol 104:239-248

Falkowskı P, Kiefer DA (1985) Chlorophyll a fluorescence in phytoplankton: relationship to photosynthesis and biomass. J Plankton Res 7:715-731

Ferreyra GA, Schloss 1, Demers S, Neale PJ (1994) Phytoplankton responses to natural ultraviolet irradiance during early spring in the Weddell-Scotia Confluence: an experimental approach. Antarct J US 29:268-270

Franklin LA, Forster RM (1997) The changing irradiance environment: consequences for marine macrophyte physiol. ogy, productivity and ecology. Eur J Phycol 32:207-232
Garcia-Pichel F (1994) A model for internal self-shading in planktonic organisms and its implications for the usefulness of ultraviolet sunscreens. Limnol Oceanogr 39: $1704-1717$

Garcia-Pichel F, Castenholz RW (1993) Occurrence of UVabsorbing, mycosporine-like compounds among cyanobacterial isolates and an estimate of their screening capacity. Appl Environ Microbiol 59:163-169

Garcia-Pichel F, Wingard CE, Castenholz RW (1993) Evidence regarding the UV sunscreen role of a mycosporinelike compound in the cyanobacterium Gloeocapsa sp. Appl Environ Microbiol 59:170-176

Goes Jl, Handa N, Taguchi S, Hama T, Saito H (1995) Impact of UV radiation on the production patterns and composition of dissolved free and combined amino acids in marine phytoplankton. J Plankton Res 17:1337-1362

Guillard RRL, Ryther JH (1962) Studies of the marine planktonic diatoms Cyclotella nana Hustedt and Detonula confervaceae (Clev) Gran. Can J Microbiol 8:229-239

Jeffrey SW, Haxo FT (1968) Photosynthetic pigments of symbiotic dinoflagellates (zooxanthellae) from corals and clans. Biol Bull Mar Biol Lab Woods Hole 135:149-165

Jeffrey SW. Humphrey GF (1975) New spectrophotometric equations for determining chlorophylls $a, b, c_{1}$ and $c_{2}$ in higher plants, algae and natural phytoplankton. Biochem Physiol Pflanz 167:191-194

Jokiel PL, York RH (1984) Importance of ultraviolet radiation in photoinhibition of microalgal growth. Limnol Oceanogr 29:192-199

Karentz D (1994) Ultraviolet tolerance mechanisms in antarctic marine organisms. In: Weiler CS, Penhale PA (eds) Uitraviolet radiation in Antarctica: measurements and biological effects. Antarct Res Ser 62:93-110

Karentz D. Cleaver JE, Mitchell DL (1991a) Cell survival characteristics and molecular responses of Antarctic phytoplankton to ultraviolet-B radiation. J Phycol 27:326-341

Karentz D, McEuen FS, Land MC, Dunlap WC (1991b) Survey of mycosporine-like amino acid compounds in Antarctic marine organisms: potential protection from ultraviolet exposure. Mar Biol 108:157-166

Kerr JB, McElroy CT (1993) Evidence for large upward trends of ultraviolet-B radiation linked to ozone depletion. Science 262:1032-1034

Kishino M, Takahashi M, Okami N, Ichimura S (1985) Estimation of the spectral absorption coefficients of phytoplankton in the sea. Bull Mar Sci 37:634-642

Landry LG, Chapple CCS, Last RL (1995) Arabidopsis mutants lacking phenolic sunscreens exhibit enhanced ultraviolet- $B$ injury and oxidative damage. Plant Physiol 109:1159-1166

Lesser MP (1996) Acclimation of phytoplankton to UV-B radiation: oxidative stress and photomhibition of photosynthesis are not prevented by UV-absorbing compounds in the dinoflagellate Prorocentrum micans. Mar Ecol Prog Ser 132:287-297

Lesser MP, Cullen JJ, Neale PJ (1994) Carbon uptake in a marine diatom during acute exposure to ultraviolet $\mathrm{B}$ radiation: relative importance of damage and repair. J Phycol 30:183-192

Marchant HJ, Davidson AT, Kelly GJ (1991) UV-B protecting compounds in the marine alga Phaeocystis pouchetii from Antarctica. Mar Biol 109:391-395

Mitchell BG (1990) Algorithms for determining the absorption coefficient of aquatic particulates using the quantitative filter technique. SPIE Vol 1302 Ocean Optics 10:137-148

Montecino V, Pizarro G (1995) Phytoplankton acclimation and spectral penetration of UV irradiance of the central 
Chilean coast. Mar Ecol Prog Ser 121:261-269

Nakamura $H_{1}$ Kobayashi J, Hirata Y (1982) Separation of mycosporine-like amino acids in marine organisms using reversed-phase high-performance liquid chromatography. J Chromatogr 250:113-118

Neale PJ, Banaszak AT, Jarriel C (1996) UV photoprotection by mycosporine-like amino acids is spectrally specific in Gymnodinium sanguineum. J Phycol (suppl) 32(3):34

Neale PS, Spector AM (1994) Ultraviolet absorbance by diatom populations from the Weddell-Scotia Confluence. Antarct J US 29:266-267

Ohad I, Kyle DJ, Anntzen DJ (1984) Membrane protein damage and repair: removal and replacement of inactivated 32-kilodalton polypeptides in chloroplast membranes J Cell Biol 99:481-485

Porra RJ, Thompson WA, Kriedmann PE (1989) Determination of accurate extinction coefficients and simultaneous equations for assaying chlorophylls $a$ and $b$ extracted with four different solvents: verification of the concentration of chlorophyll standards by atomic absorption spectra. Biochim Biophys Acta 975:384-394

Renger G, Völker M, Eckert HJ, Fromme R, Hohm-Veit S, Gräber P (1989) On the mechanism of photosystem II deterioration by UV-B irradiation. Photochem Photobiol 49: 97-105

Richter M, Rühle W, Wild A (1990) Studies on the mechanism. of photosystem 2 photoinhibition. 1 The involvement of toxic oxygen species. Photosynth Res 24:237-243

Rundel RD (1983) Action spectra and estimation of biologically effective UV radiation. Physiol Plant 58:360-366

Samuelsson G, Oquist G (1977) A method for studying photosynthetic capacities of unicellular algae based on in vivo chlorophyl fluorescence. Physiol Plant 40:315--319

Sokal RR, Rohlf FJ (1981) Biometry. WH Freeman and Company, New York

Editorial responsibility: Otto Kinne (Editor), Oldendorf/Luhe, Germany
Spotte S, Adams G. Dubucio PM (1984) GP2 medium is an artificial seawater for culture or maintenance of marine organisms. Zoo Biol 3:229-240

Strid A, Chow WS, Anderson JM (1990) Effects of supplementary ultraviolet-B radiation on photosynthesis in Pisum sativum. Biochem Biophys Acta 1020:260-268

Thompson PA, Harnson PJ, Parslow JS (1991) Influence of irradiance on cell volume and carbon quota for ten species of marine phytoplankton. J Phycol 27:351-360

Vernet M, Brody EA, Holm-Hansen O, Mitchell BG (1994) The response of antarctic phytoplankton to ultraviolet radiation: absorption, photosynthesis, and taxonomic composition. In: Weiler CS, Penhale PA (eds) Ultraviolet radiation in Antarctica: measurements and biological effects. Antarct Res Ser 62:143-158

Vernet $M$, Neori A, Haxo FT (1989) Spectral properties and photosynthetic action in red-tide populations of Prorocentrum micans and Gonyaulax polyedra. Mar Biol 103: $365-371$

Vernet M, Whitehead K (1996) Release of ultraviolet-absorbing compounds by the red-tide dinoflagellate Lingulodinium polyedra. Mar Biol 127:35-44

Villafañe VE, Helbling EW, Holm-Hansen O (1994) Effects of solar ultraviolet radiation on antarctic phytoplankton during springtime ozone depletion. Antarct J US 29: $259-262$

Vincent WF (1980) Mechanisms of rapid photosynthetic adaptation in natural phytoplankton communities. 2. Changes in photochemical capacity as measured by DCMU. induced chlorophyll fluorescence. J Phycol 20:201-211

Yentsch CS, Yentsch CM (1982) The attenuation of light by marine phytoplankton with specific reference to the absorption of near-UV radiation. In: Calkins $J(e d)$ The role of solar ultraviolet radiation in marine ecosystems. Plenum Press, New York, p 691-700

Submitted: March 2, 1998; Accepted: July 7, 1998 Proofs received from author(s): October 30, 1998 